introducing the student to informed and realistic thinking

in the whole area of relations between the states

\title{
INTERNATIONAL RELATIONS
}

The World Community in Transition, 2nd edition

NORMAN D. PALMER AND HOWARD C. PERKINS

both of the University of Pennsylvania

"I want to report excellent results from my use of Palmer-Perkins INTERNATIONAL RELATIONS this summer. The book is stimulating, compact in its presentation of an immensely complicated subject, and teachable. The authority of the authors' background makes the students respect the text, and it is a book to lean on heavily no matter how independent the lecturer likes to be. I recommend it highly and shall continue to use it."

870 pages $\quad 1957 \quad \$ 7.25$

WILLIAM L. SMYSER

State Teachers College

East Stroudsburg, Pa.

studying international organizations as part of the total pattern of world political, economic, and ideological pressures

\section{ORGANIZING FOR PEACE}

International Organization in World Affairs

DANIEL S. CHEEVER AND H. FIELD HAVILAND, JR.

Harvard University The Brookings Institution

“. . . . This is a balanced book: it gives enough weight to the non-political functions of the U.N. thus emphasizing the fact that no International Organization can survive unless it concerns itself with the social, economic, and cultural conditions of the world as well as the political."
917 pages $1954 \quad \$ 7.5^{\circ}$
Fauzi M. NajJar
Michigan State University

tracing clearly and thoroughly the development of the British parliamentary system, with opportunity for comparison with our own

\section{BRITISH PARLIAMENTARY DEMOCRACY}

\author{
SYDNEY D. BAILEY
}

"This is a well written, lively introduction to British government, which combines an acknowledgment of the importance of historical background with an emphasis upon the present-day operation of the system. Much of the illustrative material is fresh, interesting, and to the point."

281 pages, paperbound $195^{8} \$ 2.75$

American Political Science Review September, $195^{8}$

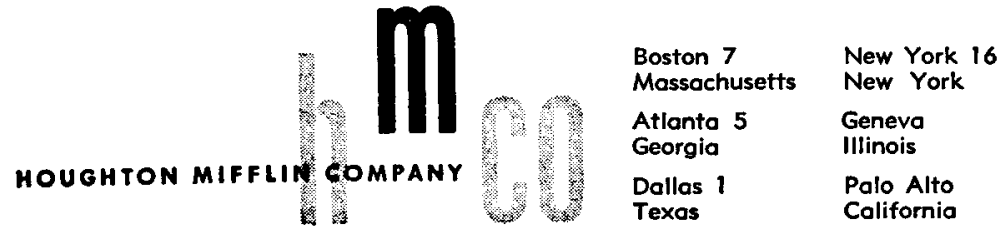




\section{in the Winter issue of THE MIDDLE EAST JOURNAL}

"KuRds and the Revolutyon In IraQ"

C. $J$. Edmonds reviews the role of the Kurdish population in the recent events.

"Politics and VIOLEnCE IN Morocco"

Douglas Ashford examines the difficulties of a newly-independent state.

"Democracy aNd the Revolution IN Egypt"

Don Peretz assesses the extent to which Egypt can be called democratic.

"Demographic and Ethnographic Changes in Transcaucasia" Richard Pipes traces developments in Georgia, Armenia and Azerbaijan over the last sixty years.

"The Labor Movement in Syria"

Aziz Allouni describes the growth of the movement since independence.

Price of the issue, $\$ 1.50 \quad$ Year's subscription, $\$ 6.00$

THE MIDDLE EAST INSTITUTE

1761 N ST., N.W. WASHINGTON 6, D.C.

\section{THE REVIEW OF POLITICS}

\section{A Quarterly Published by \\ The University of Notre Dame}

The April, 1959 issue will include the following articles:

James Johnson Sweeney: Contemporary Art: The Generotive Role of Play Jan Triska and Howard E. Koch, Jr.: The Asian-African Nations and International Organization

Charles F. Mullett: Ancient Historians and "Enlightened" Reviewers

Stephen D. Kertesz: Diplomacy in the Atomic Age-Port II

Bernard G. Murchland: The Philosophy of Gabriel Marcel

Theodore D. Lockwood: A Study of French Sociolist Ideology

John L. Morrison: William Seton: A Catholic Darwinist

Single issues $\$ 1.50$

Annual subscription $\mathbf{\$ 5 . 0 0}$

Address: THE EDITORS, REVIEW OF POLITICS

P. O. Box 4, Natre Dame, Indiana 


\section{$\begin{array}{lllllllll}U & N & I & V & E & R & S & I & T\end{array}$}

$P R E S S$

\section{Political Theory}

\section{The Foundations of 20th-Century Political Thought} By ARNOLD BRECHT

This distinguished work is a pioneering attempt to offer a comprehensive modern political theory. In surveying the philosophical and scientific foundations of political theory in the 2oth century, Arnold Brecht's wideranging treatise sweeps over the entire scope of this century's contributions including the philosophical, juridical, sociological, scientific, methodological, and historical. "It is definitely a fundamental work and will take its place as a contribution of first rank to that important subject."-William Ernest Hocking.

618 pages. $\$ 12$

\section{New England State Polities}

\section{BY DUANE LOCKARD}

A lively, fact-filled study of New England state politics in which the author shows who has political power and under what circumstances it can be used, who can nominate or influence nomination for major offices, and who can pull great weight with the legislator, the governor, or administrators. "With a sharp eye for the significant, Lockard sets out in bold strokes the dominant features of the political systems of these states. Nor does he pull his punches. Here are the rivalries among the ethnic groups, the excesses of special interests, the weaknesses and strengths of the political parties, the vicissitudes of the vanishing Yankee, all related with insight, humor, and compassion."-V. O. Key, Jr.

360 pages. Maps \& Charts. $\$ 6$

\section{Matthias Erzberger and the Dilemma of German Democracy}

By KLAUS EPSTEIN

Could Germany have been democratized without the catastrophe of World War I? Was she compelled by objective circumstances to sign the armistice in 1918? Was there any alternative to accepting the Treaty of Versailles? Such questions as these are scrutinized anew in this study of the life and times of Matthias Erzberger, which deals with German politics before, during, and after World War I.

464 pages. $\$ 10$

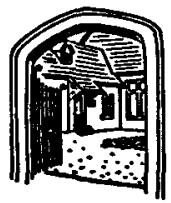

Order from your bookstore, or

PRINCETON UNIVERSITY PRESS

Princeton, New Jersey 


\section{INTERNATIONAL ORGANIZATION}

Contains in Volume XIII, Number 1, Winter 1959

\section{J. Antieles}

Early Stages in the Organization of SHAPE Lt. Col. William A. Knowlton

United States Attitude toward Domestic Jurisdiction

in the United Nations

M. S. Rajon

Negotiating the Statute of the International

Atomic Energy Agency

Bernhard G. Bechhoefer

\section{Comprehensive Summaries}

Recent activities of United Nations organs and of the specialized agencies

Recent activities of major regional and functional organizations

III. Selected Bibliography

Pertinent books and articles in American and foreign periodicals

$\$ 5.00$ a year

student rate

$\$ 1.50$ a copy

$\$ 3.50$ a year

WORLD PEACE FOUNDATION

40 Mt. Yernon Street

Boston 8, Mass., U.S.A.

\section{Norway-Sweden}

\section{Union, Disunion, and Scandinavian Integration}

\section{By Raymond E. Lindgren}

Although they were amalgamated in a union from 1814 to 1905 , Norway and Sweden were unable during that troubled period to achieve political integration. Only after the union ended in r9o5 did the Scandinavian countries establish a security community, committed to economic cooperation and to the settlement of international disputes by peaceful means. In this book, the author examines some of the problems faced by Norway and Sweden during the union and some of the forces which contributed to its failure and its termination. Dr. Lindgren also studies the present state of Scandinavian integration and offers some conclusions to be gained from this study.

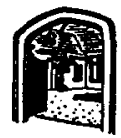

$$
\begin{gathered}
\text { Order from your bookstore, or } \\
\text { PRINCETON UNIVERSITY PRESS } \\
\text { Princeton, New Jersey }
\end{gathered}
$$

